\title{
AN ANALYSIS OF INFLECTIONAL AFFIXES ERROR IN ARGUMENTATIVE WRITING
}

\author{
Widhiya Ninsiana ${ }^{1}$ \\ Lukmanul Hakim ${ }^{2}$ \\ Institut Agama Islam Negeri Metro, Lampung \\ Email: tantowidi@yahoo.co.id
}

\begin{abstract}
This is a collaborative study which aims at explicating the errors on using inflectional affixes in students' argumentative writing of the fifth semester, English Department of the State Islamic Institute of Metro. This includes into a descriptive-qualitative research which focuses on the use of two data sources of primary and secondary data. The primary data is obtained from argumentative writing texts written by the fifth semester students of IAIN Metro. While the secondary data were collected from other supporting documents such as textbooks and articles published in journal. Additionlly, the study applies Creswell's model to analyze the data. The findings show that there are 9 argumentative writing results, they have eight errors in using $\{-\mathrm{s}\}, 2$ errors in using $\{-\mathrm{es}\}, 1$ error in using $\{-$ ies $\}, 13$ errors in using $\{-$ ed $\}, 3$ errors in using $\{-$ ing $\}$, and there is no error in using $\{-$ er $\}$ and $\{-$ est $\}$. Based on the data, the first error that commonly found in students' writing production is the use of $\{-$ ed $\}$, and the second one is the use of $\{-\mathrm{s}\}$, and the third one is the use of $\{-\mathrm{es}\}$. Most of the fifthsemester students of the English Department of IAIN Metro have lack of knowledge about inflectional affixes and there are many students who feel difficult in deciding which one is the correct affix for the word they want.It means there are many students of the fifth semester of English Department of IAIN Metro that still cannot use the inflectional affixes correctly. The conclusion of the research is the student of the fifth semester of English Department of IAIN Metro need attention to focus on writing argumentative learning and semantic especially 'inflection affixes'.
\end{abstract}

Keywords: Inflectional affixes, grammar, writing.

\section{INTRODUCTION}

Writing is one of the four underlying skills in learning English language. In addition to that, writing engages the optimlly use of linguistic elements such as vocabulary, grammar, organization, spelling, and punctuation. In the second year of Junior High School, the basic competency which should be achieved in writing English subject is that students are encourged to a certain degree to have the abilityin both developing and producing written simple function in recount, narrative, and descriptive, report texts etc.
Furthermore, there are a lot of aspects in writing, one of which is inflectional affixes. The word "inflectional" relates to expanding or changing the function of a word. Hence, the term affix in this case is called inflectional since its task is to expand the grammatical function within the word. These are the affixes which share similar grammatical functions that do not change class of the word, these words constaintly follow derivational affixes.

In this study, we will describe in detail on several affixes, such as derivational affix \{-dom\}. The word "king" is attached to the derivational affix $\{$-dom $\}$ to create the word 
"kingdom." Although both are nouns, they are semantically different in meaning. One refers to a monarch and the other to a territory by which a monarch rules over. However, the plural "kings" has an inflectional affix. The words "king" and "kings" only differ in number. Though "king" and "kingdom" are both nouns, many derivational affixes change class of the word. For example, the word "windy" is composed of the noun "wind" and the affix $\{-y\}$. When the noun combines with the derivational affix $\{-y\}$, the result is the adjective "windy."

There are eight inflectional affixes in English for the third person singular present $\{-s\}$, the past tense marker $\{-$ ed $\}$, the continuous marker $\{$-ing\}, the past particle $\{-$ en $\}$, the plural marker $\{-\mathrm{s}\}$, the possessive marker $\{-' s\}$, the comparative suffix $\{-$ er $\}$ and superlative suffix $\{-$ est $\}$. Here are examples affixes:
1. She loves hockey.
5. The children ate all their vegetables.

\section{He waited patiently.}

\section{They are}

\section{watching TV.}

4. Haven't eaten lunch yet.

6. Peter's car is new.

7. Peter's car is newer than mine.

The underlined words above are inflectional affixes. Those words should be affixed due to grammatically influenced. Hence, they do not change the meaning or class of words.

Below, the examples of students' error in using inflectional affixes (affix $\{-\mathrm{s}\},\{-\mathrm{es}\}$, and $\{$-ies $\}$ ) in students' writing paper works:

\section{Table 1}

The Students' Error In Using Inflectional Affixes

\begin{tabular}{ccc}
\hline No Question & $\begin{array}{c}\text { The } \\
\text { Correct } \\
\text { Answer }\end{array}$ & $\begin{array}{c}\text { Students' } \\
\text { Answer }\end{array}$ \\
\hline
\end{tabular}

\begin{tabular}{|c|c|c|c|}
\hline 1 & $\begin{array}{l}\text { He (pray) } \\
\text { every day. }\end{array}$ & $\begin{array}{l}\text { He prays } \\
\text { every day. }\end{array}$ & $\begin{array}{l}\text { Student 1: } \\
\text { He prayes } \\
\text { everyday. } \\
\text { Student } 2 \text { : } \\
\text { He prais } \\
\text { everyday. }\end{array}$ \\
\hline 2 & $\begin{array}{l}\text { She (try) to } \\
\text { eat it. }\end{array}$ & $\begin{array}{l}\text { She tries } \\
\text { to eat it. }\end{array}$ & $\begin{array}{l}\text { Student 1: } \\
\text { She trys to } \\
\text { eat it. } \\
\text { Student 2: } \\
\text { She tryes } \\
\text { to eat it. }\end{array}$ \\
\hline 3 & $\begin{array}{l}\text { I see five } \\
\text { (wolf). }\end{array}$ & $\begin{array}{l}\text { I see five } \\
\text { wolves }\end{array}$ & $\begin{array}{l}\text { Student 1: } \\
\text { I see five } \\
\text { wolfs. } \\
\text { Student 2: } \\
\text { I see five } \\
\text { wolfes. }\end{array}$ \\
\hline
\end{tabular}

From the above data, most students are still many found using the error inflectional affixes. Among them feel difficult in terms of using and adding the affixes, i.e., on the use of $\{-\mathrm{s}\}$ for the third singular present, in addition to the use $\{-i e s\}$ in case the final letter of the word is $y$ in which the letter before is consonant. Bearing in mind the case of inflectional is a grammatically and morphologically small significant element within a sentence, then it is important to understand and to master the better use of inflectional affixes.

Unfortunately, students of English Education Department of IAIN Metro remain unable to overcome such errors of inflectional affixes use. This may occur due to a number of reasons, among others, the students have not fully master the inflectional affixes use, in addition to students' lack of attention on the sentences, and more possibly among them do not completely understand the English language.

Considering the aforementioned background, the writers formulate the reseach problems as follows: (1) what errors are found in the students of fifth semester IAIN Metro's argumentative writing, in 
terms of using the inflectional affixes? ; (2) Why did the students of IAIN Metro in fifth semester remain doing errors in using inflectional affixes?

A research initially conducted by Gonzalez and Laudanna (1992) discusses about "the inflection-derivation continuum and the Old English suffixes -a, -e, -o, -u." Another research is by Elisa Torres (2010) from Universidad de La Rioja. The journal addresses the question of the continuity between inflection and derivation as posed by the Old English suffixes -a, -e, -o-u. From the structural perspective, the undertaken morphological analysis focuses on the overlapping inflectional and derivational phenomena. However, in the functional perspective, affixation is analyzed in the constituent projection and inflection in the operator projection of the Layered Structure of the Word (LSW), where the derivational affix constitutes a morphological pivot and the inflectional affix a morphological controller.

The second, research entitled "Processing Inflectional and Derivational Morphology." The research was conducted by Alessandro Laudanna, et al (1992:333348), from stituto di Psicologia, CNR, Rome, Italy. Three lexical decision experiments were carried out to investigate the nature of morphological decomposition in the lexical system. The first of these experiments compare the priming effect of inflectionally and derivationally related forms on a simple inflected word. Experiments two and three compared the effect on forms like mute of priming by an infected stem homograph (mutarono) and priming by a derived "roothomograph" like mutevole-a morphologically unrelated derived word with homographic root (mut-).

Based on the research above, inflectional affix is a small thing in English learning but it becomes an important thing in writing skill. However, the research did not yet concern on error the analyzing by using inflectional affixes. Therefore, the writer will conduct the research to analyze the error in using inflectional affixes in students' writing. Moreover, the research will be taken on English Education Study Program.

This research is qualitative research with a case study approach research. Data source divided into two part, namely, primary and secondary data. The primary data was students document in argumentative writing of English Department of IAIN Metro. The secondary data was collected from archival data such as the accumulated survey information documents of IAIN Metro.

\section{LITERATUREREVIEW}

\section{Inflectional Affixes}

Carstairs (1997: 28) states that inflection is words that do not have to be listed because they are merely grammatically contained variants of a word that is more basic in some sense and which itself may or may not be listed, depending on whether its meaning is predictable or not.

An inflectional morpheme does not have the capacity to change the meaning of the syntactic class of the word it is bound to and will have a predictable meaning for all such words inflection is the morphological marking of property on a lexeme resulting in a number of forms for that lexeme. In English Morphology, the inflectional morpheme is a suffix that is added to a word to assign a particular grammatical property to that word. In other words, the inflectional morpheme is used only for grammatical purposes. Inflectional morphemes serve as grammatical markers that indicate tense, number, possession, or comparison. Only English nouns, verbs, adjectives, and adverbs - all open classes of words-take inflectional affixes. Inflectional always follow derivational ones if both occur in a word, which makes 
sense if we think if inflections as affixes on fully formed words. For example, the word antidisestablishmentarianism and compartmentalize each contain a number of derivational affixes, and any inflectional affixes must occur at the end: anti disestablishment Arianism and compartmentalized. Thus, the present tense will mean the same thing regardless of the verb that is infected.

Furthermore, Karlos Kuriaki (2007:110) explains that inflection is a change made in the form of a word to show its grammatical relations. Inflectional changes sometimes take place in the body of a word, or at the beginning, but oftener in its termination. Terminations of inflection had possibly originally independent meanings which are now obscured. They probably corresponded nearly to the use of prepositions, auxiliaries and personal pronouns in English.

Inflection changes in the body of the verb usually denote relations of tense or mood, and often correspond to the use of auxiliary verbs in English. The inflection of Nouns, Adjectives, pronouns and participles to denote gender, number and case is called declension, and these parts of speech are said to be declined. The inflection of verb to denote voice, mood, tense, number and person is called conjunction, and the verb is said to be conjugated. Rochelle Lieber states that inflection refers to word formation that does not change category and does not create new lexemes, but rather changes the form of lexemes so that they fit into different grammatical contexts (2009:88). As we will see below in detail, grammatical meaning can include information about number (singular vs. plural), person (first, second, third), tense (past, present, future), and other distinctions as well.

\section{The Use of Inflectional Affixes}

In English morphology commonly there are eight functions of inflectional affixes; the third person singular present $\{-\mathrm{s}\}$, the past tense marker $\{-\mathrm{ed}\}$, the continuous marker $\{-i n g\}$, the past particle $\{-$ en $\}$, the plural marker $\{-\mathrm{s}\}$, the possessive marker $\{-' s\}$, the comparative suffix $\{-$ er $\}$ and thesuperlative suffix $\{-$ est $\}$.

\section{a. Nouns}

Most countable nouns in English have two-word forms, they are a singular and a plural. We have noted that $\{-\mathrm{s}\}$ is the regular suffix for forming a plural, like $a$ cat-cats, hero - heroes. Irregular suffixes express plurality include $\{-\mathrm{i}\},\{-\mathrm{ae}\},\{-\mathrm{a}\}$ (as in cacti, formulae, and phenomena); the suffix $\{-(\mathrm{r}) \mathrm{en}\}$ that shows up in children, brethren, and oxen; and a very few others such as the $\{-\mathrm{im}\}$ inKibbutzim and cherubim. There are also some countable nouns that express their plural with no suffix at all, as in man - men, tooth - teeth, mouse - mice. However, there are also some whose plurals display not even a vowel change, like sheep, fish, trout, and deer.

All the changes mentioned above are the forms of an inflectional morpheme. The affixes used only changes the grammatical purpose, not the grammatical category. In addition, it gives the information about the number of the nouns stated.

\section{b. Pronouns and Determiners}

Determiners deserve a mention here because some of them display singularplural contrast and pronouns combine the singular-plural contrast with contrast unique to them, between subject and nonsubject forms.

1) Determiner divided into two part, such as singular (this and that) and plural (these and those)

2) Pronouns are divided into subject pronoun, object pronoun, possessive adjective and possessive pronoun. A subject pronoun as I, you, they, we, he, she and it. Object pronoun like me, you, them, us, him, her, and it. Possessive 
adjective example my, your, their, our, his, her, and it. The possessive pronouns are mine, yours, theirs, ours, his, hers, its. Possessive meaning for the particular pronoun such as the man, a cat, etc, using apostrophe $\left\{-{ }^{-} \mathrm{s}\right\}$, for example, the man's bicycle is broken.

3) Forms of verbs. Inflectional verbs

a) The third singular pronoun in simple present (as in performs).

b) Past tense (as in performed).

c) Present progressive (as in performing).

d) Perfect or passive participle (as in performed).

In English, there are more than 150 irregular verbs that do not use suffix $\{-$ ed for past progressive and past participle. Nevertheless, they still have past tense and past participle form, e.g. freeze - froze frozen. Moreover, there are also irregular verbs whose past tense and past participle form display, not even a letter change, as in bet - bet - bet, hit - hit - hit, and bid bid - bid.

1) Forms of adjectives. Inflectional adjectives are used to express comparison degree. Look at the table below:

\begin{tabular}{lll}
\hline Positive & Comparative & Superlative \\
\hline Happy & Happier & Happiest \\
Untidy & Untidier & Untidiest \\
Cheap & Cheaper & Cheapest \\
& More & Most \\
Expensive & expensive & expensive \\
Good & Better & Best \\
\hline
\end{tabular}

2) Forms of adverbs. The inflectional adverb is used in comparison degree, for example, soon - sooner - soonest, early - earlier - earliest, and quickly - more quickly - most quickly.

\section{Argumentative Writing}

As one of four basic skill of language, writing is very important because it constitutes the clarification of someone's thought and feeling. Through this skill, the students can explore their own thinking, a various feeling, and also the concept of using word or papers. In writing indeed, the students can express their ideas, thoughts, and fact in well-formed structure.

Related to the final product of writing, it has to agree with the several compositions in writing. Brown H.Douglas (2001:335) said that, "A good deal of attention was placed on "model" compositions that students would emulate and on how well a student's final product measured up against a list of criteria that include content, organization, vocabulary use, grammatical use, and mechanical considerations such as spelling and punctuation.

Based on the statement above, it infers that in writing a person can arrange letters, words, sentences, and paragraph by using the knowledge of structure systematically in written forms and hopes the reader understand what he means.

It can be noted that the final product of writing has to well organized, the message comprehensible, an argument is relevant and related to the writer's view. Main ideas and effective supporting ideas are clearly stated. Also, the language is clear, smooth, and interesting. there are no major errors in vocabulary, spelling, punctuation, and grammar.

Sanggam Siahaan (2008: 215) states "writing is the psychology activity of the language used to put information in the written text". Through writing the student can realize their information in a text. According to Jordan, writing is a method used by human to conduct intercommunication by means of conventional visible marks or symbols. It is also used to deliver or to communicate nonverbal message, idea, expression, feeling, or thought. Through a piece of writing human being construct their communication in various ways (2003: 41). 
Meanwhile, according to Kane (2000:7) said that writing in its broad sense-as distinct from simply putting words on paper that has three steps: thinking about it, doing it and doing it again. As often as time will allow and the patient will endure.

On the other hand, Brown explains that writing is a process of composing multiple drafts in order to make an effective product (1998:335). It can be organized a thought, ideas, and feeling. In composing process, the draft is crucially needed as a first step to develop ideas. Without drafting it is hard to begin that process. After developing the thought or ideas, the revision should be applied in order that it gained a good product. Written products are frequently produced from the result of thinking, drafting, and revising procedures.

Based on the above quotations, it can be inferred that writing is basically the processing ideas and thoughts by using knowledge of structure and vocabulary to combine our ideas as a means communication. Writing is one of nonverbal communications that requires the linguistic skill. It is used by the people to share their thoughts, feelings, and ideas with others. It needs a composing process in order that it produces a good product. The products of writing take a form in the written result that it should be comprehended in order for a good communication to take place.

There are many types of writing. One of them is argumentative writing. Argumentation is used in persuading and convincing. Argumentation is often combined with exposition. Argumentation is used to make a case or to prove or disprove a statement or proposition. It illustrates that argumentation consists of several statements to be obtained the point of view. Persuasive is a verbal art that the purpose is to make a people do something that the writer said at this time or the future (2010:1016).

\section{FINDINGS AND DISCUSSION}

\section{Text 1}

Recently MUI issued a fatwa that smoking is forbidden and should be avoided. The prohibition of smoking causes a variety of reactions in the community. The society is divided into two groups in considering fatwa issued by MUI. Most of the people agree with the MUI. However, the others do not agree with MUI.

The party who agree with MUI assumes that smoking is very dangerous for humans since it may cause various disease and even cause for death. The danger of smoking is not only bad for the smoker but also bad for people around them. It can cause death, impotence, internal organs damage, heart and many more. Based on this fact, MUI issued that smoking is haram because basically anything that causes damage is unlawful and should be avoided.

From the data above, the first student is still wrong in using inflectional affixes. The student is still wrong in using verb base after «be», still wrong in using the verb after a plural noun, and still wrong in wringing verb after the modal.

\section{Text 2}

Education is a form of the factor which can reflect how's the country look like, Development or developing? Indonesia is the developing country. We are not a poor country like others countries in the Africa continent. Based on the fact, The education which as the main factor to build the great generation.

Education is the strongest way to survive, as the key to assesses of someone's successes. On the scope of the state, education is the main instrument in the formation of a future generation. The success of a country depends on the quality of Human Resources Indonesia, with one 
of the ideals contained in the preamble of the 1945 constitution, as like paragraph 4 «intellectual life of the nation» as the promise of independence. Only exceptions to reach that goal is a knowledge.

The second student writes a verb "survive" after verb base which this is the wrong writing and the word "exceptions" while he writes an article "an" before it that should be written by "exception".

\section{Text 3}

This rubbish is anywhere. This can be seen all around us. Rubbish is usually derived from the people who irresponsible and lazy to throw things in a wrong place. Rubbish that gathered it cause abadodor that pollute the air. In addition, the scrapheap into a nest of various disease that are very dangerous. Source of the disease will be carried away with the air so that it will be inhaled by us. As a result, we become sick and of course also be transmitted to others who breathe the same air.

In this case, the student made 4 errors in using the inflectional affixes within one paragraph. The first error is in writing verb after "to" which should be written by verb base "to wasting" becomes "to waste". The second error is that the student still use verb base in past tense form. The third error is the using of plural noun afterword "various. And the last error is the writing of "carried" which should be written by "carried".

\section{Text 4}

Drug contains a lot of substances that are harmful to human's body. One of them is the addictive substance. This substances which would interfere with our nervous system. Addictive substances that have entered into the body will require the brain to continue to consume. As a result, the drug would be the withdrawal consuming and cannot be separated from the drug.

In this section, the student still does the same error as the others, such as the use of singular noun afterword "some" and the writing of verb base afterword "have".

\section{Text 5}

Adolescent behavior today has come out very far from moral values prevailing in society. It is caused by several factors. The first factor is independent of western culture into Indonesia. The incoming culture copying and using as a new habit by teens today, unfortunately, that behavior is replicate is the bad behavior of the culture, such as casual sex, drugs, and others. The second factor is the weakness of religious knowledge possessed by the teenagers. In fact, the science of religion very useful because they can control themselves to avoid a bad deed. The latter is a lack of parental supervision. Parents are much responsible for the behavior of children. Parents who does not care about his son would make them feel unloved finally they seek affection outside it. This is what will make them fall into the wrong crowd. As a result of factors, hence the behavior of today's youth be contrary to the values - values that exist.

From the data above, the student writes a word "cause" after to be "is" and the word "factor" after "several" which should be written by "factors". In this part, the student is wrong in using verb in the past sentence and the wrong verb after plural noun.

\section{Text 6}

The cost of education in Indonesia is very expensive. Although the government has provided assistance, 
but still the students have to pay some costs for school needs, such as clothing, books, and others. The high cost of education is not only limited to the elementary school, but also in college. Even the cost of education at the campus extremely expensive because the government does not provide direct assistance to college. Many children who after graduating from high school prefers to look for a job rather than to continue in college. As a result, education in Indonesia is not evenly distributed and concentrate only on the person who is able to alone. As for people who are less capable, higher education is just a dream.

The next student does the same error like the others. After auxiliary verb "has" the students should write verb past participle "provided" instead of "provide". The second error is the writing of word "distribute" and "concentrate", the student should write "distributed" and "concentrated".

\section{Text 7}

There are a lot of people say that globalization has damaged Indonesia's economic system. Globalization is now be usher Pancasila Economic System is owned by Indonesia to the Economic System of Capitalism. There is also said that globalization make networking and media distribution of the economic system becomes wide. Of course, is very helpful on the magnitude of opportunity for Indonesia to participating in the international economic system. But basically good or bad of globalization it is certain that all depends on how the limits and rules regarding globalization itself.

From the data above, there are three errors written by the student. The writing verb after to be "is", verb after singular noun, and verb after "to".

\section{Text 8}

Corruption has become a big and serious problem for our nation. Can see from the news broadcast Republika newspaper (December 17, 2002), which states that the House of Representatives was to mobilize support for the establishment of the Special Committee to investigate the alleged misuse of funds KORPRI Rp900 billion over 10 years under the leadership of Chairman KORPRI Feisal Tamin. Corruption also occur in bodies which should takes care of people's welfare, among others in Social Security. SOE also has long been a den of thieves tie and collar (neck shirt) white.

There are only two errors in this part. The student writes verb "occur" after noun "corruption" which should be written by "occurs" and the verb "takes" after modal "should" which should be written by "take".

\section{Text 9}

In developing countries, the index of poverty rate is define as the proportion of people with income of less than US $\$ 1$ per day based on price priority purchasing power decreased $28.3 \%$ in 1987 to $24 \%$ in 1998 . The decline in the poverty rate cannot keep pace with growth population and many of the poor in developing countries increases by about 160 million between 1987 and 1998. at the end of the twentieth century, the problem of poverty increased in many countries, especially in Southeast Asia that directly affects the 1997 financial crisis

The word "define" after to be "is" should be written by "defined" and 
"increases" should be written by "increased". The student is wrong in writing the word "country" after "many" which should be written by "countries" because it is the plural noun.

From the data analysis above,, the errors accumulation in argumentative writing of the fifth semester of English Department of IAIN Metro.

Table 2

\section{A Number of Error of Students' Argumentative Writing by using Inflectional Affixes}

\begin{tabular}{cccccccccc}
\hline \multirow{2}{*}{ No } & Text & \multicolumn{6}{c}{ INFLECTIONAL AFFIXES } \\
& $\mathbf{1 - 9}$ & -s & -es & -ies & -ed & -ing & -er & -est \\
\hline 1 & AA & - & 1 & - & 2 & 1 & - & - \\
2 & AAA & 1 & - & - & 1 & 1 & - & - \\
3 & CNA & 1 & - & - & 2 & - & - & - \\
4 & EA & 1 & - & - & 1 & - & - & - \\
5 & HR & 1 & 1 & - & 3 & - & - & - \\
6 & LN & - & - & - & 3 & - & - & - \\
7 & LNB & 1 & - & - & - & 2 & - & - \\
8 & LTK & 2 & - & - & - & - & - & - \\
9 & NH & - & - & 1 & 2 & - & - & - \\
\hline
\end{tabular}

The table shows the number of errors in using inflectional affixes that have been done by the students. The student 1 did 4 errors, 2 in using $\{-e d\}, 1$ in using $\{-e s\}$ and 1 in using $\{-i n g\}$. The student 2 did 2 errors, 1 in using $\{-s\}$ and 1 in using $\{-e d\}$. The student 3 did 4 errors, 1 in using $\{-s\}$, 2 in using $\{-e d$ \}and 1 in using $\{-i n g\}$. The student 4 did 2 errors, 1 in using $\{-s\}$ and 1 in using $\{-e d\}$. The student 5 did 5 errors, they are 1 in using $\{-s\}, 1$ in using $\{-e s\}$, and 3 in using $\{-e d\}$.

On the other hand, the student 6 did 3 errors in using $\{-e d\}$. The student 7 did 3 errors, 1 in using $\{-s\}$ and 2 in using $\{-i n g\}$.
The student 8 did 2 errors in using $\{-S\}$. The student 9 did 3 errors, 1 in using $\{-i e s\}$ and 2 in using $\{-e d\}$. So the last student did only 1 error in using $\{-S\}$.

From nineargumentative writing, there are fifth errors in using $\{-S\}, 2$ errors in using $\{-e s\}, 1$ error in using $\{-i e s\}, 13$ errors in using $\{-e d\}, 3$ errors in using $\{-i n g\}$, and there is no error in using $\{-e r\}$ and $\{-e s t\}$. Based on the data, the first error that commonly found in students' writing production is the use of $\{-e d\}$, and the second one is the use of $\{-s\}$, and the third one is the use of $\{-e s\}$.

\section{CONCLUSION}

The kinds of errors encountered by the students is that noun, pronoun, and determiner. From nine argumentative texts, there are eight errors in using $\{-s\}, 2$ errors in using $\{-e s\}, 1$ error in using \{-ies\}, 13 errors in using $\{-e d\}, 3$ errors in using $\{-i n g\}$, and there is no error in using $\{-e r\}$ and $\{-e s t\}$. Based on the data, the first error that commonly found in students' Argumentative writing is the use of $\{-e d\}$, and the second one is the use of $\{-S\}$, and the third one is the use of $\{-e s\}$.

Based on the result of the data analysis, the writer eagerly is going to deduce this research that many kinds of errors are still found in using inflectional affixes by students of the English Department of IAIN Metro such as the students of the fifth semester of English Education Department of IAIN Metro are having lack knowledge about inflectional affixes, and they feel difficult in deciding which one is the correct affix for the words they want, there are too many words in a paragraph.

The implication is that it is hoped that the analysis and results of this research satisfy the interest of the language teachers, translators, text book writers, syllabus designers as well as students concerning the use of inflectional affixes. 


\section{REFERENCES}

Booij, Geert, 2005, The Grammar of Word, New York, Oxford University Press,

Boardman, Cynthia A. and Frydenberg, Jia, 2008. 2 Writing to Communicate: ParagraphandEssays ThirdEdition, New York, Pearson Longman.

Brown, H.Douglas, 1998, Teaching by Principle, London: Longman.

Creswell, John W., 2012, Educational Research Planning: Planning, Conducting, and Evaluating Quantitative and Qualitative Research, $4^{\text {th }}$ Edition, Boston: Pearson Education Ltd.

Creswell, John W., 2007, Qualitative Inquiry and Research Design: Choosing among Five Approaches, California: Sage Publications Inc.,

Galko, Francine D., 2001, Better Writing Right Now, Learning Express, New York,

Hornby, A.S., 2010, Oxford Advance Learner's, New York, Oxford University Press, the eight edition

Keraf, Gorys, 2001, Narasi and Argumentasi, Jakarta, Gramedia Pustaka Utama.

Kuriaki, Karlos, 2007, A Grammar of Modern Indo-Europian, Europian Union.

Laudanna Alessandro, et al, 1992, Processing Inflectional and Derivational Morphology: Journal of Memory and Language, 31, 333348

Rochelle, Lieber, 2009, Introduction Morphology, Cambridge University Press
Starke, Lauren, 2004, How to write with a Great Essays, Learning Express, New York.

MacKay,Donald G, 1979,Lexical Insertion, Inflection, and Derivation: Creative Processes in Word Production: Journal of Psycholinguistic Research, (8), 5,

Marianne Celce-Murcia, 2000, Discourse and Context in Language Teaching, (United States of America: Cambridge University Press,)

Mc. Crimon, 1983, Writing A Purpose, Houhton Miffin, New York,

MikeSharples, 1999, How We Write Writing as Creative Design ,(London and New York, The Taylor \& Francis Group,)

Nikky Gamble and Sally Yates, 2002, Exploring Children' Literature. Paul Chapman Publishing, London. First published

R.R Jordan, 2003, Academic Writing Course, England: Longman,

Spencer Andrew, 1997, Morphological TheoryAn Introduction to Word Structure in Generative Grammar, Oxford

Thomas S. Kane, 2000, Oxford, Essential Guide to Writing, New York, Berkley Books,

Torres Elisa González, 2010, The Inflection-Derivation Continuum and the Old English Suffixes -a, -e, -o, -u: Journal of the Spanish Association of Anglo-American Studies. Vol.32.1.

Urquhart, V., and Mclver, M., Teaching Writing in the Content Areas, ASCD Alexandria, Virginia, McREL Aurora, Colorado, USA 